assistant director of the Solar Physics Observatory, Cambridge, followed by his election to the chair of natural philosophy in the University of Aberdeen, he joined the Admiralty Department of Scientific Research and Experiment as an assistant director to Sir Charles S. Wright in 1942, expecting to return to the University of Aberdeen on the conclusion of hostilities. Invited by the Admiralty to take up a permanent appointment following the Second World War, he resigned his chair to become director of physical research in 1945 and was appointed to the senior scientific post in the Admiralty, deputy for research and development to the Controller of the Navy and scientific adviser to the Board of Admiralty on October 1,1946 , which post he occupied until its change in title and status on April 1, 1964. Sir John's principal field of research was astrophysics, during which his most noteworthy contribution was the development of a method for determining the rotational speeds of stars from an analysis, by Fourier transforms, of the observed profiles of stellar absorption lines. He participated in several expeditions to observe total eclipses of the Sun but was, with one exception, dogged by bad weather. In Aberdeen he took a keen interest in both research and teaching and substantially reorganized the courses in his Department; he was elected to the University Court. In his long tenure of his Admiralty office he was responsible for the overall organization and supervision of Naval Research and Development and the application of science to Naval problems, and made outstanding use of the dual features of his appointment in promoting the integration of military and scientific thought, an activity he pursued more widely over the years as a member from its inception under Sir Henry Tizard of the Defence Research Policy Committee.

Mr. B. W. Lythall

Mr. B. W. Lixthall, who succeeds Sir John Carroll, was born in 1919 and joined the experimental branch of H.M. Signal School, later to become the Admiralty Signal and Radar Establishment, in December 1940, after reading physics at Christ Church, Oxford, where he gained an M.A. From then until the end of 1953 he was engaged in various aspects of radar research and development, initially on generation of high-power microwave pulses and afterwards on most aspects of microwave techniques. For the last few years he specialized in aerial practice at microwave and other frequencies, and was in charge of the station where this work was conducted. In 1954 he moved to the Admiralty Research Laboratory, Teddington, to join a new group working on under-water acoustics research, and later in the same year was promoted to senior principal scientific officer in charge of the group. In 1957 he became assistant director of physical research at the Admiralty, and in October 1958 was promoted deputy chief scientific officer and returned to the Admiralty Signal and Radar Establishment to take charge of the department concerned with radar research and development and allied topics. In October $1960 \mathrm{Mr}$. Lythall was appointed chief scientific officer plus and moved to Portland to become the first chief scientist of the newly created Admiralty Underwater Weapons Establishment. This was an amalgamation of the former H.M. Underwater Detection Establishment and the Underwater Weapons Establishment. The latter had itself been formed in 1959 from three earlier establishments in Greenock, Havant and Bournemouth, so that the new complex represents the final stage of the Admiralty plan for the concentration at Portland of four hitherto separate organizations working on various aspects of research and development in the under-water field.

Psychology in the University of Nottingham : Prof. W. J. H. Sprott

WrTH the retirement of Prof. W. J. H. Sprott at the end of the present academic year, the University of Notting- ham will lose one of Britain's most distinguished social scientists. It will also lose one of its own oldest and most loyal servants. Prof. Sprott was a student of psychology and philosophy, flavoured with Bloomsbury, at Clare College, Cambridge, in the early twenties. He camo to University College, Nottingham, as it then was, in 1925, and for many years occupied something of a settee, as he termed it, in philosophy and psychology. Later his interests turned also to social psychology and sociology. He was professor of philosophy from 1948 until 1960, and latterly professor of psychology. He has been the University's public orator since 1948. His publications include General Psychology (1937), Sociology (1949), Philosophy and Common Sense (1949), Living in Crowds (1949), Social Psychology (1952), Science and Social Action (1954), Human Groups (1958), and Sociology at the Seven Dials (1962). He delivered the Josiah Mason Lectures at the University of Birmingham in 1958. He continues as editor of the International Library of Sociology and Social Reconstruction. Prof. Sprott was primarily a psychologist. He adhered to the old-fashioned view that this subject is concerned with human beings, and that human beings may profitably be studied from many different points of view. Few could match the breadth of knowledge and sympathy which he brought to this task. His permanent contribution will probably lie in the field of social psychology where, as a rather lonely figure, he continued and developed the tradition so ably begun by Rivers and McDougall. His many friends will hope that they may long continue to enjoy his wit, humanity and common sense.

Prof. C. I. Howarth

Dr. C. I. Howarth, at present lecturer in psychology at the University of Hull, has been appointed to succeed Prof. Sprott in the chair of psychology and as head of the Department of Psychology in the University of Nottingham. Dr. Howarth entered Balliol College, Oxford, as an Open Scholar in 1947. After graduating in chemistry and later in psychology and physiology, he was awarded a grant from the Medical Research Council to enable him to undertake research at the Oxford Institute of Experimental Psychology, for which he was awarded the degree of D.Phil. in 1956. While on National Service in the Royal A.ir Force, he conducted independent research on visual problems of high performance flight, which he continued under an Air Ministry grant after his release from the Service. In 1958 he was appointed to his present position at Hull, and in 1961-62 went to Stanford University, California, as a special lecturer and U.S. Public Health Service Fellow. Dr. Howarth's research work has been in the fields of temporal characteristics of human vision, the mechanisms underlying threshold decisions and on the physiological mechanisms of learning.

\section{The Langley Medal of the Smithsonian Institution}

Astronaut Alan B. Shepard, JUN., pioneer American space flyer, has been awarded the Langley Medal of the Smithsonian Institution for his "courageous and pioneering contributions to scientific research as the first American to fly in space and the first to control the attitude of a spacecraft while in flight and during a condition of weightlessness". Commander Alan Shepard, as he then was, manned the Freedom 7 spacecraft in sub-orbital space on May 5, 1961 (Nature, 190, 568, 587; 1961). The Langley Medal was established in 1908 and named after Samuel Pierpont Langley, aviation pioneer and secretary of the Smithsonian Institution from 1887 until 1906. It has been previously awarded only ten times since it was established. It was last awarded to Prof. Hugh L. Dryden in 1962.

New Scheme for Experience in Science, Engineering and Technology

The United Kingdom Atomic Energy Authority and the Central Electricity Generating Board have announced 